\title{
PROVISION OF INTERNATIONAL EDUCATIONAL SERVICES BASED ON NUS EXPERIENCE
}

\author{
Alexander Sergeevich Ryzhkov \\ Admiral Makarov National University of Shipbuilding, Mykolaiv, Ukraine
}

CMESTE

JEL Category: 121, 123, M12

\begin{abstract}
With increasing competition in the global education sphere, the only way to a decent functioning of the Higher Educational Institutions of Ukraine is to match the high international standards. This cannot be achieved without active international activities aimed at the development of international educational programs. In the "Admiral Makarov" National University of Shipbuilding, in Mykolaiv, there are successfully implemented several joint educational programs with foreign partners. Based on experience, it was developed project management methodology for the provision of educational services to the foreign customer. The mechanisms of the implementation of key programs in terms of project management are being studied. The development of Sectoral Distribution of Responsibility for project management training programs " $2+2$ " and " $4+0$ " with Chinese partner was performed. Implementation of the specialized training program "Junior Specialist (Associate Bachelor) - Bachelor" is considered. The project management mechanisms of implementation of the specialized training programs with Vietnamese partners are also considered. They are proposed as fundamental approaches of project management that are applicable to a variety of other programs that already exist, or are planned to be implemented.
\end{abstract}

Keywords: project management, promotion, education system, effectiveness-performance, international experience, knowledge management

\section{INTRODUCTION}

The formation of Ukraine as an integral partner of the European Union and serious player in the global arena is impossible without strong integration of not only economic factors, but cultural and educational components.

Address of the author:

Alexander Ryzhkov

豐=" oleksandr.ryzhkov@nuos.edu.ua
The Association Agreement between Ukraine and the European Union signed on June 27, 2014, includes the process of implementation of European standards into many areas of life activity and healthy operation of a State. In particular, this concerns also the educational process. Everyone knows the high standards of the West in the educational field which means the increase of the Ukrainian education level.

The globalization of the educational services market causes the transformation of national 
education systems of many countries. As a strongly marked indicator of this phenomenon, there can be such countries as the USA, the UK, South Korea, Eastern Europe countries, etc. For Ukraine, as for other European countries, except the system reforms, the most important factor of higher education reformation is the introduction and development of the Bologna process as a consequence of globalization (Bobrytska, 2013).

On June 19, 1999, 29 European Ministers of Education signed the Bologna Declaration (Vassiliou, 2010) which became the catalyst for the development and modification of the Sorbonne Declaration ideas (Leuven and Louvain-la-Neuve, 2009) on the European Higher Education Area. It promotes closer contacts between European countries in the development and strengthening of intellectual, social, scientific and technological potentials, academic and general cultural enrichment.

The academic mobility of students, a wide degree of autonomy in decision-making and active international activity are the most important components of the successful life activity of European universities. Considering the European model of education, we should take into account a factor of competitive activity. The educational services of the West are connected to the market economy and act according to the simple and hard "supply and demand" law. The specialty which is not interesting for the market employment cannot compete and the university has to cut it with all its consequences (redundancy, a decrease of study load, etc.). In fact, the ability of Western universities to adapt to the constant changes of our time is the key to a successful operation.

Accepting the European standards, the Ukrainian higher educational establishments should be aware that they accept also the conditions of healthy competition not only between each other but also between the European universities. And if the universities in the UK, France, and Germany has a little interest for the majority of Ukrainian applicants because of the historically formed circumstances of pricing and other factors, then the universities of such countries as Poland, Slovakia, and the Czech Republic look more attractive and real. The general level of satisfaction with the education system in these countries is higher than in Ukraine, as the "Report on Human Development over 2013" data evidence (UNDP, 2013).

In conditions of the increasing competition in the global education area, the correspondence to high criteria and international standards is the only way of functioning of the higher educational establishment in Ukraine. And this cannot be achieved without the active international activity which is aimed at the development of international educational programs.

Heading for the international integration, we should remember about the needs of Ukrainian regions on which the university works. Currently, there is uncoordinated work between the higher education and potential employers in conditions of development of market relations and the labor market. In the industrial regions of Ukraine, it is primarily connected with the active modernization of industrial enterprises: purchase of modern hightech equipment, usage of the latest software, expansion of the range of products. It leads to the need for constant updating of training programs for junior specialists in accordance with the realities of the regional labor market (Belikov, Klimov, Pavlenko, \& Tkach, 2013).

To achieve these aims, the management of higher educational establishment should be a balanced mix of professional managers, specialists on project management, supervisors, and teachers which can flexibly and effectively react to any circumstances of modernity.

The "Creation of a University of the European Type" program has been still fulfilling at the Admiral Makarov National University of Shipbuilding (NUS) since 2008 as a part of the "Concept of the NUS Development" (Ryzhkov A. , Management of international educational projects of National University of Shipbuilding on the example of Ukrainian-Chinese cooperation, 2014). The concepts and fulfillment of international educational programs of this university are used as the basis of this study.

\section{ANALYSIS OF RECENT ACHIEVEMENTS}

Project Quality Management includes all activities that relate to general management functions, determine the quality policy, objectives and responsibilities and implement them by such means as quality planning, its control and 
improvement within the quality assurance (Guay, n.d.), (Papke-Shields \& Boyer-Wrigh, 2017), (Bushuev, 2000).

The process of quality management project has three main components: quality planning, quality assurance, and quality control. Those methods to control the quality of the high school teachers make it difficult to perform the correct quantitative assessment. The need for this assessment indicates a large number of researcher, linking measures to motivate teachers for quality labor with the ability of the administration to have an correct assessment of teachers work (Burkov \& Novikov, 1998), (Zynnurov \& Huzayrov, 1991), (Hotomlyanskyy \& Derevyanko, 2005), (Balyhin, 2003).

At NUS it is used to consider a teacher as a person who seeks to help the student to learn the necessary knowledge and skills required by educational standards. Based on this consideration the calculation to quantify the quality of teaching is taken as a standard (Ryzhkov A. , Quality Management Education NUS program "2+2" with ZIMC, 2017), (Ryzhkov A. , 2017), (Ryzhkov A. , 2016). This calculation is used for the evaluation of the educational process for Ukraine, but for assessing the implementation of international educational programs it is applied the first time. In literature, no data on the existence of a universal computing program for calculation of a quantitative assessment of the quality of teaching. Therefore, to simplify the calculations to quantify the quality of education has been developed the computing program.

The international activities and cooperation with foreign organizations were carried out according to the "Concept of the NUS Development" and "Tasks of the National University of Shipbuilding, the vector of the development remains unchanged (Ryzhkov S. , 2013).

The object of the study is an international educational program of NUS, and the subject is the successful functioning of the mechanisms and the implementation of these programs.

The Scientific Educational Centre of International Cooperation has effectively performed the activity on attracting the foreign citizens to study at the NUS. Thus, from 2011 to 2016 there is a record tendency on the increase of foreign students, postgraduates, and trainees who want to improve their skills over the entire period of the university existence. Thus, as at the beginning of 2008, there were only 88 foreign students at the NUS. As at the beginning of February 2016, 1073 foreign citizens from 24 countries studied at the NUS. The number of foreigners at the NUS has increased in more than 13 times which is a high indicator of the dynamics of the international cooperation development (Fig. 1).

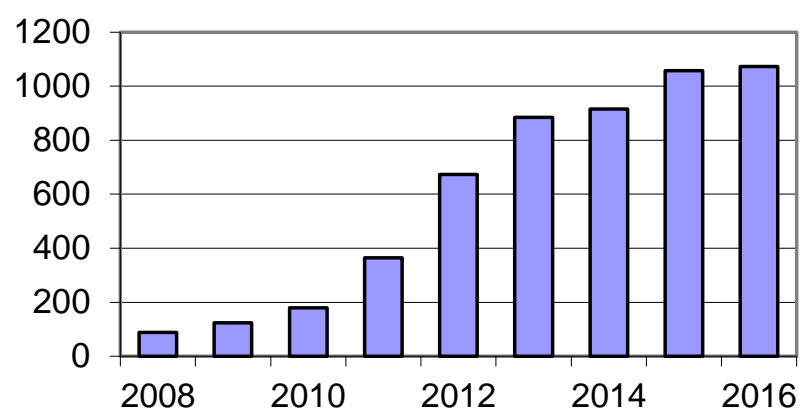

Fig.1. Number of foreign students in NUS

A training program is developing at the NUS with the International Maritime College (Zhejiang International Maritime College), Zhoushan, China. Over four years 70 Chinese graduates (junior specialists) of the college were directed in order to obtain the higher technical education (Bachelor degree) in the "Marine Engineering" knowledge field (Specialty "Ships and Ocean Engineering", "SPP") on the " $2+2$ " program. In summer 2013 the first graduation of Bachelors in this program (13 people) was held and in summer 2014 the second one (14 people) was also held. $30 \%$ of graduates continue their education in a Master's program. In 2015 - 17 people. In 2016 new group of 22 students have graduated.

The agreement with the management of the Jiangsu University of Science and Technology, China, is fulfilled on the co-operative Bachelors' training in the "Ships and Ocean Engineering" direction on the " $4+0$ " program. There were 181 students over 2012-2015. Currently, there is a campaign to enroll the fifth group.

In 2012 the agreement was signed on the Partnership and Cooperation between the Admiral Makarov National University of Shipbuilding, Mykolaiv, Ukraine and Batumi Navigational Teaching University, Batumi, Georgia. Within the cooperation, the educational counseling NUS 
center in Batumi was opened on the basis of the BNTU to fulfill the training of students on the Bachelor programs. 217 students were enrolled in the training in various specialties. Currently, there is a new admission campaign.

The negotiations have been continued and the preliminary agreements on the forms of cooperation in the direction of the Specialists' training with the government agencies and universities of Poland, Norway, Belgium, Turkey, Azerbaijan, Tajikistan, Georgia, Turkmenistan, China, Estonia, Argentina, etc. have been reached.

\section{PRESENTATION OF THE BASE MATERIAL}

Accumulated many years of NUS experience with international customers makes it possible for a rational approach creation for the project management of the foreign segment. Existing management models do not fully meet their stated objectives for the implementation of these projects. In particular, the closest models: traditional (cascade) project management methodology is not suitable because of its inertness and intolerance to changes, and popular in the West methodology PRINCE2 would make a lot of additional bureaucratic claims (Guay, n.d.).

Based on the results of the project management performed by Educational Scientific Centre of International Cooperation of NUS the project management methodology to provide the educational services to the foreign customer has been developed (Project Management for Education, PME). The processes of PMEmethodology are shown in Figure 2.

The principles of the PME-methodology:

1. Possibility Assessment, selection of performers - whether the university is able to complete an international project in accordance with the requirements of the customer, in the case of a positive assessment the necessary university structural units are picked and the team of project executors is being formed.

2. The continuous growth - to take into account the wishes of the customer, to accumulate experience.
3. The use of the mechanism of "shared responsibility" - the responsibility for a positive outcome of the project is not only the main executor headache (in common, the international structural unit of the university is the main executor), but also it is a responsibility of all other structural units that are involved in the project.

4. Evaluation of the quality of work - maintaining an unprejudiced control over the quality of educational services provided by the university. The constant desire to improve and meet the high international standards.

5. Sectoral project management - the project is divided into blocks (sectors), every sector has its executing team.

Aspects of the PME-methodology:

1. Planning - preparation for implementation of the project, verification of curricula, preparation of supporting documents, dispatching support.

2. Co-ordination - the allocation of responsibilities, the matching of structural divisions.

3. Execution - the level of compliance of planned results to the actual implementation.

4. Risks - mechanisms to solve possible contingencies in the planning and the factors of external interference.

The processes of PME-methodology:

1. Rector's control.

Rector or its authorized person conducts supervision over the implementation of the University obligations to the international customer. It is implemented throughout the project period.

2. The start of the project.

The reason for the start of the project is the international contract for the provision of educational services. It is also the plan of the project. At this stage of the project, the responsible executors are appointed and all preparatory work is carried out.

3. Project Management.

This stage is characterized by the distribution of sectoral responsibility.

4. Implementation of the project.

The fundamental stage of the project, which is a direct provision of educational services to 
international students/trainees by basic university divisions - departments.

5. Monitoring of progress.

At the expiration of the specified time period, a comprehensive monitoring of the implementation of the project to identify abnormalities and other negative factors that can hinder the implementation of the contract is being performed. Usually selected time period is an educational semester.

6. The quality of teaching monitoring.

Implemented together with the control performance and is aimed at compliance with international teaching criteria.

7. Completion of the project.

It is characterized by the implementation of terms and conditions of the contract with the issuance of diplomas/certificates to foreign citizens who have completed all requirements for the assignment of the corresponding qualification.

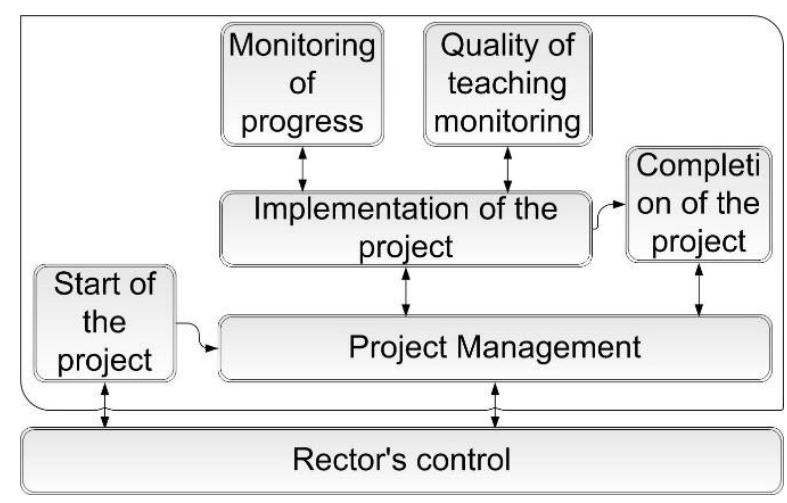

Fig.2. The processes of project management methods to provide educational services to the foreign customer

As an example, let us study the main educational programs performed by NUS for foreign partners (Ryzhkov A. , Management of international educational projects of National University of Shipbuilding on the example of Ukrainian-Chinese cooperation, 2014).

\subsection{The "2+2" Program.}

Specialty: "Ships and Ocean Engineering".

Teaching language: English.

Partner: Zhejiang International Maritime College, China (ZIMC).

Year of agreement signing: 2010.
Study duration: 2 years in China, 2 years in Ukraine.

$1^{\text {st }}$ graduation: June 2013.

The main point of this program is to train the students for a bachelor degree on the basis of twoyear training in China followed by the study continuation in Ukraine. A state-pattern diploma of Ukraine is the final result.

This is a complex project which is included in the concept of the general NUS program of formation of a University of the European type. In this context, the fulfillment of training potential in the international arena is understood.

A group of students is the input data for this project. The final aim of the project is gained when these students obtain a Bachelor's diploma. The Educational Scientific Center of International Cooperation in Ukraine and the International ZIMC office in China manage this project. The International Relations and Learning and Teaching sectors distribute the duties upon program functioning at the NUS. The success of this project can only be achieved through the close cooperation and collaboration with other university departments, mostly with the Shipbuilding Institute and its leading departments and it resembles a coherent clockwork mechanism in which everything stops in case of a unit failure.

As is shown in figure 3 , each structural subdivision which is involved in the program is responsible for specific tasks which allow successful carrying out of the project. There have already been completed two projects by July 2014: two groups graduated with Bachelor's diplomas, the total number of graduates is 27 people. In 2015, there are plans to graduate 17 new young specialists. The study continuation of some graduates of the Master's Program is a positive complementary product of this program. It should be noted, that the Master's program is carried out in Russian, so the attention is paid to the Russian language course during two years of study in English.

Basing on the experience of successful fulfillments, it should be noted, that the " $2+2$ " project is subjected to a number of problems despite the visible rational distribution of responsibilities. All the problems are based on such a concept as a "human factor". It shows itself 
both by the students and by the methodologists, specialists, and teachers. It gets also worse by the fact that a fairly low percentage of teachers knows English sufficiently to conduct lectures and practical activities in English, despite the large number of highly qualified personnel at the NUS. This is a slowing component under the integration into the global educational process and one should work seriously on this issue.

One teacher teaches several disciplines and when he/she cannot be in the class for some reasons, nobody can replace him/her. In this case, the ESCIC learning and teaching sector controls the situation. It reschedules classes for the days which are more comfortable for the teacher who missed the classes. This, in its turn, can cause other teachers' dissatisfaction, whose schedule changes as a consequence.

The solution of conflicts and minimization of harm by means of the human factor are one of the most important roles in the project of the Educational Scientific Center of International Cooperation.

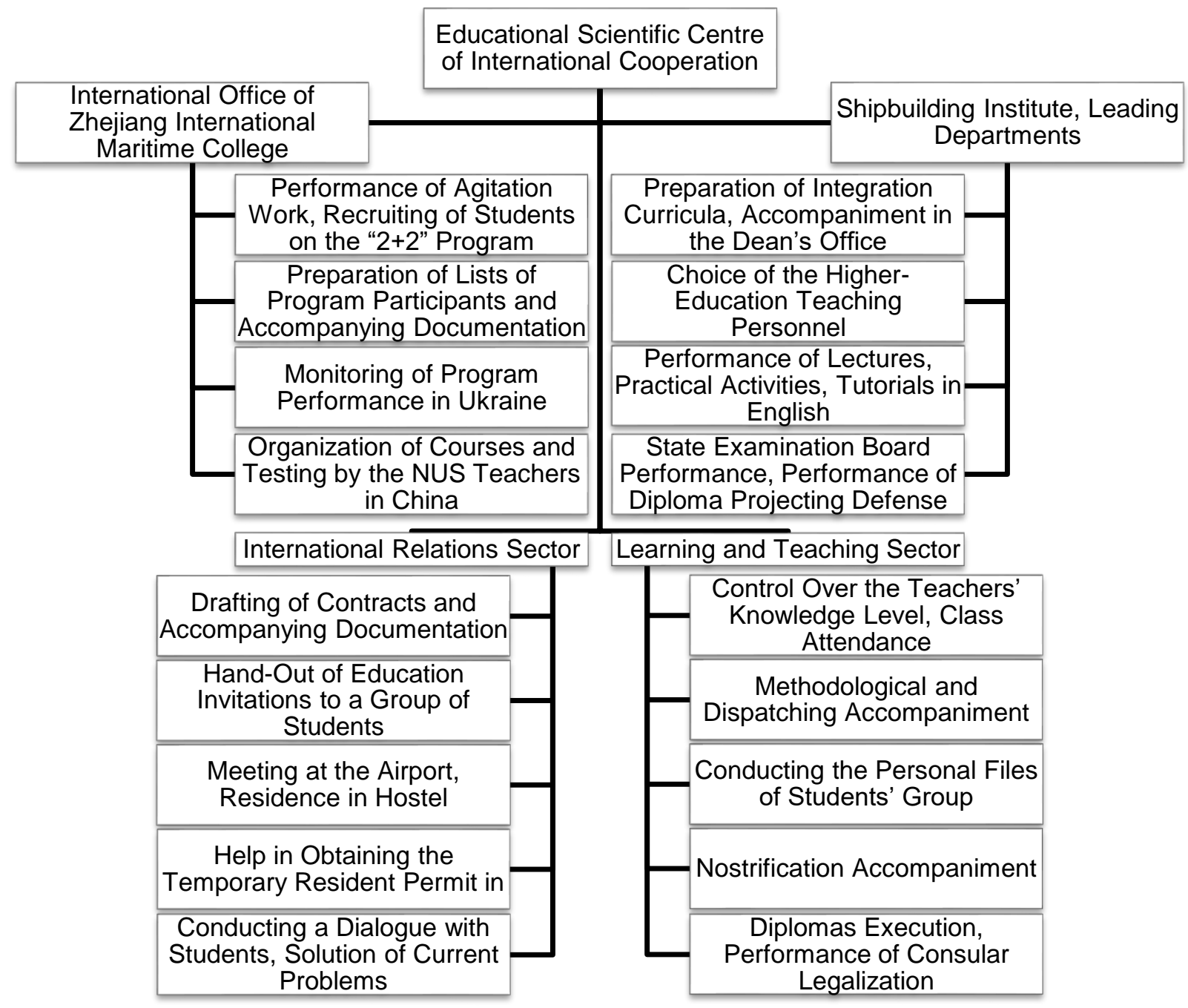

Fig.3. Sectoral Responsibility Distribution under the Project Management of the "2+2" Training Program

Only the well-coordinated work of structural subdivisions reinforced by a general program of development and formation of a University of the European type ensures the successful project fulfillment. The management of such a complex project requires the overall focus of the leaders' powers of three powerful subdivisions: the International ZIMC office, the NUS Educational Scientific Center of International Cooperation and the NUS Shipbuilding Institute. 
It should be noted, that there is a high demand in the employers' market in China on the product of this project - the graduates of the shipbuilding industry. So, all the graduates of the first group were employed at the leading enterprises in Shanghai and Zhoushan. The graduation of the second group has been held recently, so there are no current data about their employment at the moment, but the preliminaries give a reason to conclude that these graduates will find a good place in life.

\subsection{The "4+0" Program or a Double Degree.}

Specialty: "Ships and Ocean Engineering".

Teaching language: English.

Partner: Jiangsu University of Science and Technology, China (JUST).

Year of agreement signing: 2011.

Study duration: 4 years.

$1^{\text {st }}$ graduation: planned in July 2016.

The main point of this training program is to prepare bachelors on the basis of an integrated curriculum between the Admiral Makarov National University of Shipbuilding and the Jiangsu University of Science and Technology. The training is carried out in China in the JUST classrooms and laboratories with the help of both Chinese and Ukrainian teachers. The part-time and distance studying technologies are widely used. The result is a so-called "double degree", a Bachelor diploma of the Chinese state standard and a Bachelor Diploma of the Ukrainian state standard.

The double degree programs are not new to Ukrainian universities; however, their main inclination falls on a partnership with Western universities which is noted by the Ministry of Education and Science of Ukraine. But the NUS is a pioneer and leader in Ukraine in the fulfillment of such a program with the Chinese partners.

This project is also a part of the program of the NUS development and formation of a University of the European type. It is structurally multi-layered and its successful fulfillment depends on the coherence of actions, both in Ukraine and in China. If we compare it to the " $2+2$ " project, it requires much more advance preparation which also implies the approval of higher authorities.

The initial stage of the project fulfillment is to develop a common integration curriculum which will be implemented into the study process of the NUS, as well as the Chinese partner. In parallel to the curriculum development, there is work on the supplements to the main contract which will be the fundamental rules of the project fulfillment. The agreement stage begins after the approval of the integrated curriculum and supplements by the senior management of the universities. The Chinese party submits documents for the approval of the Board of the Jiangsu Education. The Ukrainian party agrees on the integrated curriculum with the Ministry of Education and Science of Ukraine. Once all the formalities are completed, the fulfillment of the program begins at the local level.

A distinct division of responsibilities between two parties is required for the successful management of this project. It is achieved by the formation of committees on both sides which are responsible for the project. These committees are responsible for the management of its project part at home university, as well as for the close cooperation with the Committee of the partner university.

From the both parties, the committee includes the Vice-Rector on the International Affairs, the Head of the International Department (Center), the director of the Shipbuilding Institute (School). In Ukraine, the committee coordinates the work of the Educational Scientific Center of International Cooperation which is responsible for the successful project fulfillment by the NUS. The duties are divided between the International Relations and Learning and Teaching sectors.

Taking Figure 4 as an example, the complexity of this project becomes obvious, because if you remove at least one component from it, the whole project is doomed to failure. Without the qualitative mechanisms of the control over the project, the final result cannot be achieved either by the performing parties or by mutual control between the partners. The key element of the control is the proper distribution of tasks, efficient monitoring conducting of their performance and, in the case of deviations from the stated conditions, efficient decision of arising difficulties. The methodology of 
planning approach is applied at the NUS to fulfill this project. It allows carrying out the systematic analysis of work readiness. Basically, a semester control system is applied.

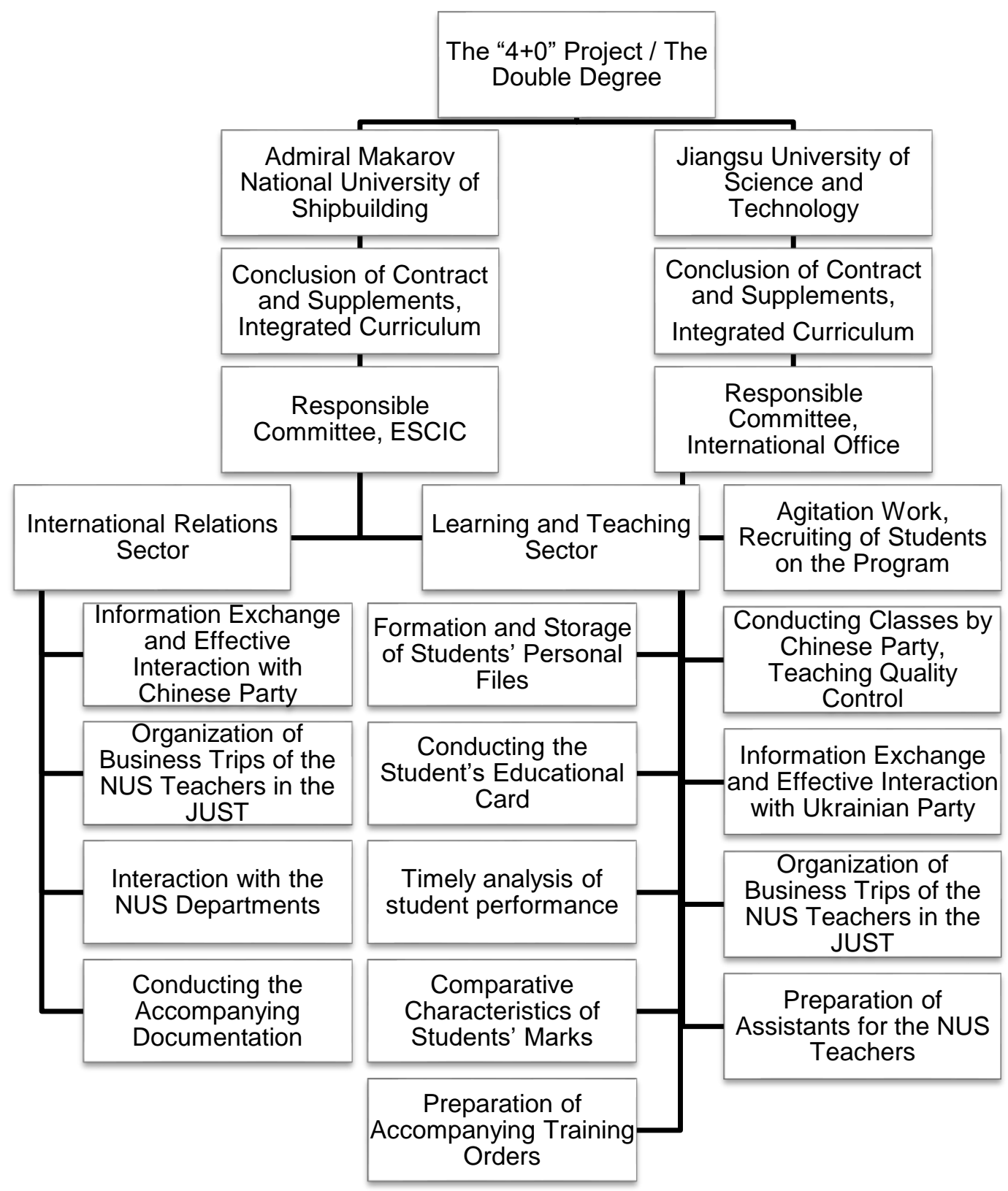

Fig.4. Sectoral Responsibility Distribution under the Project Management of the "4+0" Training Program

The effective management of the " $4+0$ " project is impossible without two key criteria:

1. close interaction and mutual understanding of the project managers with executives;

2. effective interaction with the executives of each other, especially in the "UkrainianChinese executives" tandem.

The process of forming a curriculum and supplements to the agreement to the issuing the dual degree is impossible without the strict observance of all the terms of this project. The terms (indicated in the supplements) of providing the training materials of various academic disciplines, as well as the terms of staying the NUS teachers at the JUST are a serious work indicator on this project of each of the parties. In particular, the NUS which is the executive of a number of requirements must fulfill all its duties in a certain timeline in order to achieve the common aim. Otherwise, the sanctions mechanisms will be involved which lead to the financial losses and can expose a successful project fulfillment to a risk. 
As the executives of the project, the top-class experts in their field of education and project management are selected by the NUS. The responsibility for certain training directions lies upon the department, not upon the particular individuals, because in the case of a negative response to the "human factor", the substitution is picked up by the senior executives of the department or another way is found to solve the problem.

The NUS applies successfully the mechanism of the "responsibility distribution" in which the primary responsibility for a positive result lies not only upon the main executive which is the Educational Scientific Center of International Cooperation, but also upon all other structural subdivisions of the University which are involved in the project. Therefore, a synergistic effect is achieved by the joint efforts aimed at the fulfillment of duties of the University.

As part of improving the PME-methodology, universal computing program (UCP) for calculation of a quantitative assessment of the quality of teaching in educational establishment has been developed on the basis of improved by author mathematical model that is defined by the dispersion of average score and calculated as the weighted arithmetic mean of score dispersion for each discipline, with quantitative measure calculated as the return value of the quadratic coefficient of variation.

\subsection{The " $3+X$ " Program}

Specialty: "Ships and Ocean Engineering".

Teaching language: English.

Partner: Zhejiang International Maritime College, China (ZIMC).

Year of agreement signing: 2013.

Study duration: 3 mandatory years in ZIMC at Junior Bachelor followed by an optional training in NUS at Bachelor (from 1 to 1.5 years, depending on the direction of training).

$1^{\text {st }}$ graduation: June 2016 .

\section{Objectives}

To educate and train talents in Shipbuilding and Marine Engineering, who will have a good master of both professional knowledge and English skills so as to meet the requirements of the globalization and to support the development of specialization in Shipbuilding and Marine Engineering of Zhejiang International Maritime College.

\section{Requirements}

\section{i. Knowledge Framework}

1. To have a certain amount of knowledge of humanistic disciplines, social and natural sciences.

2. To have a certain amount of general knowledge of computer operation, word processing, and a foreign language.

3. To master the specialized knowledge in ship performance, ship hull graphing, ship hull structure, ship principles and ship hull building and repairing workmanship, required for the positions of ship production and design, ship hull assembly, production management, and ship inspection.

4. To know about the developing tendency and problems in ship and ocean engineering industry under the background of globalization.

\section{ii. Skill Framework}

1. To master the production and management skills required for the positions in ship and ocean engineering enterprises.

2. To be able to use computers, do word processing, communicate properly and use a foreign language.

3. To be able to make inquiries, analyze and solve problems, and have the potential of selfdevelopment.

4. To have the abilities of organization, coordination, planning, and creation.

\section{iii. Professional Qualities}

1. To have a good psychological quality, integrity, and endurance.

2. To have a responsible professional ethic and teamwork cooperation spirit.

3. To have the design and production concept in the modern manufacturing industry, professional awareness, and creativity.

\section{Methods}

i. To focus on the combination of skill-oriented and globalization-oriented talents in ship and 
ocean engineering production and management.

ii. To combine domestic teachers with foreign teachers. Basic and specialized knowledge is provided by domestic teachers, and foreign language application and advanced techniques and concepts about shipbuilding are provided by foreign teachers.

iii. To diversify the teaching methods. In classroom teaching, teachers' teaching is combined with students' discussion. Multimedia and productive situation teaching mode is adopted in classroom teaching. In the practical course, analog training, and an integration of teaching, learning, and practice are adopted so as to trigger students' interests and teaching efficiency. In extracurricular practice, social activities during vacation and visits of other enterprises are included.

iv. To combine theory and practice. The comprehensive abilities to apply specialized knowledge to practical production and management, and to complete practical tasks will be formed in the combination teaching mode.

\section{Enrollment and Evaluation}

Students are enrolled above the enrollment mark of the third level of higher education institutions (Higher Vocational College), particularly with English Course mark of no less than 85.

In the examination of both institutions, the lowest passing mark is 60 out of 100 . Those who fail in any examination can take the make-up examination only once and shall retake the course if they fail again in the make-up examination. Zhejiang International Maritime College shall issue the graduation certificates in Shipbuilding and Marine Engineering to those who complete all the courses, and the Admiral Makarov National University of Shipbuilding shall issue the associate degree in Ship Machinery Design and Mounting to those who meet the qualifications.

\section{Teaching Management}

The management board of the Specialized Higher Education Joint Project in Shipbuilding and Marine Engineering between Zhejiang International Maritime College, China and the Admiral Makarov National University of Shipbuilding, Ukraine, is responsible for the teaching management (Figure
5). The Admiral Makarov National University of Shipbuilding shall provide syllabi and materials samples for Zhejiang International Maritime College at least 2 months before the beginning of courses. All the teaching methods shall be adopted under the approval by both institutions, with a face-to-face instruction mode. Teachers in China shall instruct in the Chinese or bilingual mode of Chinese and English. Centralized teaching mode can be adopted if necessary.

\begin{tabular}{|c|c|c|}
\hline & $\begin{array}{l}\text { Management Board of the } \\
\text { Specialized Higher } \\
\text { Education Joint Project }\end{array}$ & he \\
\hline $\begin{array}{c}\text { NUS: } \\
\text { Shipbuilder } \\
\text { College, } \\
\text { Departments }\end{array}$ & $\begin{array}{l}\text { ESCIC of NUS, } \\
\text { International } \\
\text { Office of ZIMC }\end{array}$ & $\begin{array}{c}\text { ZIMC: } \\
\text { Shipbuilding } \\
\text { School, } \\
\text { Departments }\end{array}$ \\
\hline $\begin{array}{l}\text { Information and } \\
\text { supervisory } \\
\text { support }\end{array}$ & & $\begin{array}{l}\text { Performing the } \\
\text { basic educational } \\
\text { process }\end{array}$ \\
\hline $\begin{array}{l}\text { Educational and } \\
\text { methodological } \\
\text { support }\end{array}$ & $\begin{array}{l}\text { Integrated plan, } \\
\text { Organization of } \\
\text { NUS teachers } \\
\text { visits to China }\end{array}$ & $\begin{array}{l}\text { Control of the } \\
\text { quality of } \\
\text { teaching, } \\
\text { organizational } \\
\text { issues }\end{array}$ \\
\hline
\end{tabular}

Fig. 5. Segment distribution of responsibilities in the management of the training program " $3+X$ "

To guarantee the quality, both institutions shall design the syllabi jointly, share the teaching materials, exchange the curriculum table, examination papers and students' assignments, the management group have the right to check and verify the teaching facilities of both institutions in advance.

\subsection{Training programs with Vietnamese partners}

In the case of the Socialist Republic of Vietnam, the direct work with the Vietnamese state-owned company "High Technology Application Company" is being performed. The company acts as the customer of educational services at NUS for Vietnamese citizens and working on saturation with graduates of various industries of the country.

In the period from 2004 to 2017 has been signed and performed/executing right now nine contracts for the training of Vietnamese citizens. The peak value of the number of students while studying in NUS are 2012 and 2013 years, (45 people every 
year). While in 2000 the number of Vietnamese students was only 3 humans.

It should be noted that the specifics of the company's orders is a comprehensive training of highly qualified professionals, which is carried out in three different training models:

1. Basic education "Bachelor-Master".

2. Ph.D. training.

3. Professional Development.

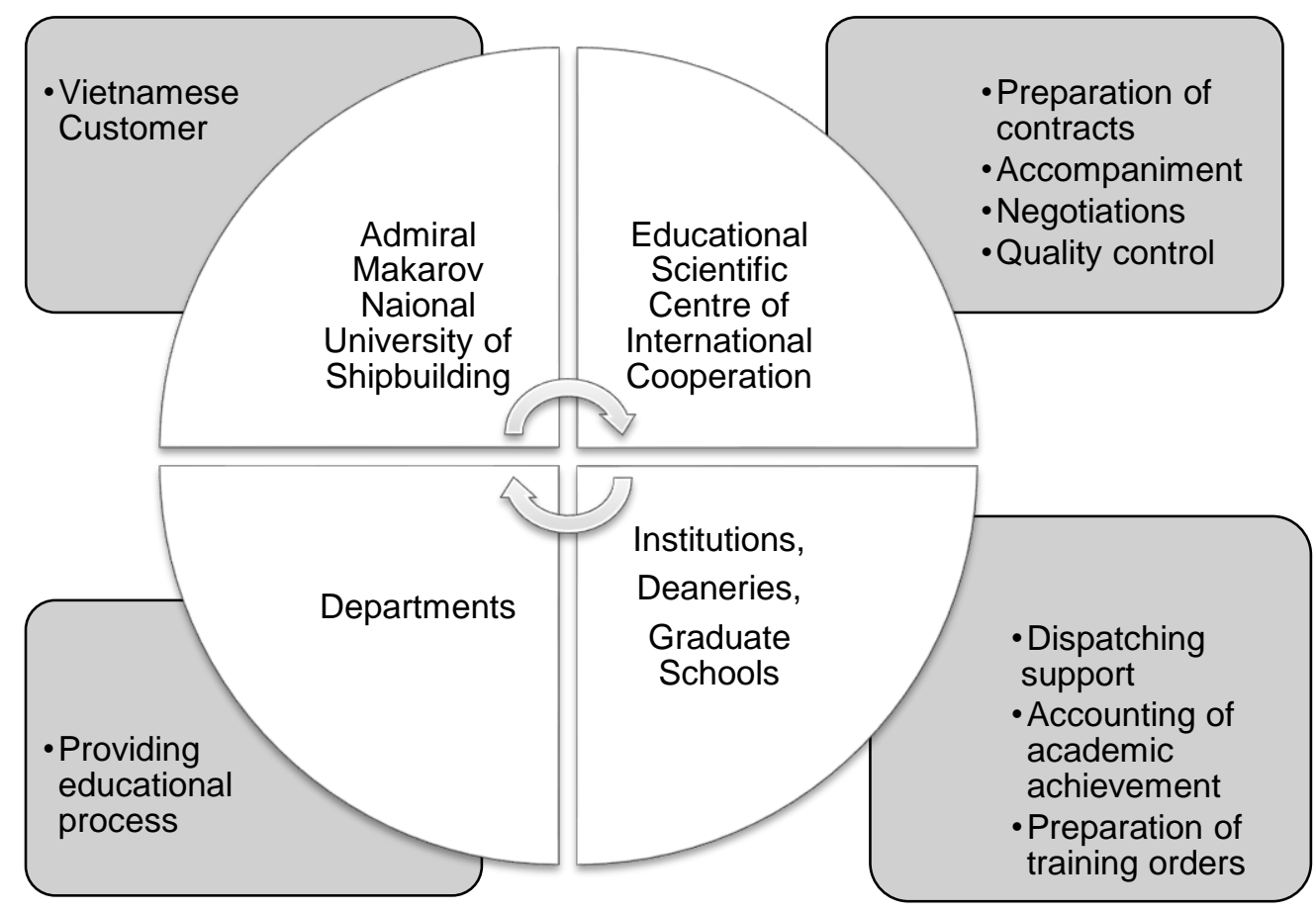

Fig.6. Project Management Cyclic Matrix for a Vietnamese customer

As can be seen from the Project Management Cyclic Matrix for a Vietnamese customer (Figure 6 ), the responsibility is distributed as follows.

Educational Scientific Centre of International Cooperation prepares contracts with customers, leads the negotiations and support, from issuing invitation letters to obtaining a visa to foreign citizens and ending with removal from accounting registration in the regional department of the State Migration Service of Ukraine. Also in the international center is to control the quality of the provision of educational services. Widely used universal computing program for calculation of a quantitative assessment of the quality of teaching developed in NUS by the head of ESCIC A. Ryzhkov (Ryzhkov A. , 2017), (Ryzhkov A. , 2016).

These structural units of the University, as institutions, deaneries, Graduate Schools responsible for methodical and supervisory support for the project. The monitoring function for the academic performance also is performed by them. Also, their duties include executing internal document flow at the University.

Summary division of the University - Department, is the basic order executor, providing educational services by conducting lectures, practical and laboratory classes.

\section{CONCLUSIONS}

Based on the results of the project management performed by Educational Scientific Centre of International Cooperation of NUS the project management methodology to provide the educational services to the foreign customer has been developed (Project Management for Education, PME).

This methodology allows to effectively manage international educational projects, which is confirmed by its application in a successful implementation of a number of international contracts of NUS. 
Summing up main NUS international curricula with Chinese partners, we can conclude that the similar fundamental approaches of project management can be applied to other international projects despite their differences. They are also applied for various existent programs or programs which are planned to be fulfilled by the higher educational establishments.

After reviewing the implementation of international educational programs with Vietnamese partners in the Admiral Makarov National University of Shipbuilding for the period from 1996 to 2017 years we can conclude that in the conditions of modern globalization trends and competition in the field of education for universities the successful implementation of international projects for the provision of educational services possible due to clear coordination and optimal distribution of functional responsibilities between the executing departments.

This method of management is recommended to use for the universities, who wish to be competitive on the international market of educational services.

\section{WORKS CITED}

Balyhin, G. (2003). Management education development, organizational-economic aspect. Moscow: Economics.

Belikov, S., Klimov, O., Pavlenko, D., \& Tkach, D. (2013). Regional labor market - a factor that determines the training of young specialists. Higher Education in Ukraine, 113-116.

Bobrytska, V. (2013). Mobility as a key principle of forming a European educational space. Higher Education in Ukraine, 234 - 238.

Burkov, N., \& Novikov, D. (1998). Models and Mechanisms theory of active quality management systems in the preparation of professionals. Moscow: Research Center of quality control specialists preparation.

Bushuev, S. (2000). Guidelines for Project Management: Transl. from English. Kiev: Publishing house "Business Ukraine".

Guay, M. (n.d.). Project Management 101: The Complete Guide to Agile, Kanban, Scrum and Beyond. Retrieved from zapier.com: https://zapier.com/learn/project-management/project-managementsystems/

Hotomlyanskyy, O., \& Derevyanko, T. (2005). Building Balanced Scorecard. Universities and Education Management. Vol.8. - №2., 49-53.

Leuven and Louvain-la-Neuve. (2009). The Bologna Process 2020 - The European, Higher Education Area in the new decade. Retrieved from Communique of the Conference of European Ministers Responsible for Higher Education: http:// www.bologna2009benelux.org

Papke-Shields, K. E., \& Boyer-Wrigh, K. M. (2017). Strategic planning characteristics applied to project management. International Journal of Project Management, 35(2), 169-179.

Ryzhkov, A. (2014). Management of international educational projects of the National University of Shipbuilding on the example of Ukrainian-Chinese cooperation. Zbirnik Naukovih Prats NUS number 6, 84 - 91.

Ryzhkov, A. (2016). Development of a methodology to provide educational services to the foreign customer project management. NUS Journal, Nikolaev.

Ryzhkov, A. (2017). Quality Management Education NUS program "2+2" with ZIMC. Collections of the Scientific works NUS №1.

Ryzhkov, A. (2017). Quality Management Education NUS program "3+X" with ZIMC. The International collections of the Scientific works NUS №1, 2017. 
Ryzhkov, S. (2013). Report of the Rector for 5 years. Mykolaiv: NUS Publishing.

UNDP. (2013). Human Development Report 2013. The Rise of the South: Human Progress in a Diverse World. New York.

Vassiliou, A. (2010). Focus on Higher Education in Europe 2010: The Impact of the Bologna Process. European Commission, Education, Audiovisual and Culture Executive Agency. EC. doi: $10.2797 / 38158$

Zynnurov, U., \& Huzayrov, M. (1991). Comments expenses for the preparation of professionals in dependence from qualification requirements for the graduate. Moscow: ITs.

Received for publication:

27.02.2017

Revision received:

20.03.2017

Accepted for publication:

27.03.2016

\section{How to cite this article?}

Style - APA Sixth Edition:

Ryzhkov, A. S. (2017, July 15). Provision of international educational services based on NUS experience. (Z. Čekerevac, Ed.) MEST Journal, 5(2), 125-137. doi:10.12709/mest.05.05.02.14

Style - Chicago Sixteenth Edition:

Ryzhkov, Alexander Sergeevich. "Provision of international educational services based on NUS experience." Edited by Zoran Čekerevac. MEST Journal (MESTE) 5, no. 2 (July 2017): 125137.

Style - GOST Name Sort:

Ryzhkov Alexander Sergeevich Provision of international educational services based on NUS experience [Journal] // MEST Journal / ed. Čekerevac Zoran. - Toronto - Belgrade : MESTE, July 15, 2017. - 2 : Vol. 5. - pp. 125-137.

Style - Harvard Anglia:

Ryzhkov, A. S., 2017. Provision of international educational services based on NUS experience. MEST Journal, 15 July, 5(2), pp. 125-137.

Style - ISO 690 Numerical Reference:

Provision of international educational services based on NUS experience. Ryzhkov, Alexander Sergeevich. [ed.] Zoran Čekerevac. 2, Toronto - Belgrade : MESTE, July 15, 2017, MEST Journal, Vol. 5, pp. 125-137. 